\title{
Observed activities of serum creatine kinase: total and $B$ subunit activity and other enzymes in young persons abusing solvents
}

\author{
RJ SPOONER, ${ }^{*}$ RC BIRRELL, AS McLELLAND, JA BAIRD, I SOURINDHRIN
}

From the Department of Biochemistry, Royal Infurmary, and Departments of Psychiatry, Royal Infurmary and Duke Street Hospital, Glasgow

SUMMARY Serum enzymes (aspartate transaminase, alanine transaminase, alkaline phosphatase (ALP), $\gamma$-glutamyltransferase, and creatine kinase (CK)) were measured in 296 young persons who admitted to recent inhalation of solvents, usually toluene based glues. In general, results fell within expected adult reference ranges except for ALP and CK. About $60 \%$ of subjects had CK activities above the upper reference limit and these activities were investigated in terms of their isoenzyme composition.

CK B subunit activity was measured in 90 subjects with raised total CK activities. In five instances the CK B subunit activity was judged abnormal and in two subjects the presence of CK BB was confirmed. These two subjects were thought to have a circulating macro CK, type 1 .

It is concluded that the increased total CK activity found in this group of solvent abusers was due to physical activity, but a contribution from specific muscle toxicity by solvents cannot be excluded.

Solvent abuse among young persons has been widely described in the media and popular press and in professional journals. As with any substance abuse there can be social, psychological, and physical complications. The full extent of the last of these is not yet known, although specific problems such as encephalopathy, ${ }^{1}$ epileptiform attack, ${ }^{2}$ and hepatorenal damage ${ }^{3}$ have been reported in the UK and a range of uncommon serious toxic effects have been reported in North America. ${ }^{4}$

The prevalence of solvent abuse is such that examination of abusers must continue so that more knowledge is gathered about morbidity. Biochemical organ profiling plays an important role in this respect.

Information on reference ranges for serum enzymes in this young age group is limited. Moreover, it may be outdated following the recent introduction of new methods for their measurement

* Present address: Department of Biochemistry, Gartnavel General Hospital, Glasgow.

Accepted for publication 15 December 1983 recommended by national societies. General trends may be drawn, however, from the published work.

Creatine kinase (CK) is particularly sensitive to exercise, ${ }^{5}$ and previous workers reporting CK activities in normal children have assumed that raised values are due to recent physical activity, ${ }^{67}$ repeat samples showing a reduction in enzyme activity. ${ }^{7}$ The observed increases in CK activity in this age group have never been explained in terms of the isoenzymes of CK.

In 1979 a psychiatric outpatient department was introduced specifically for the referral of young persons abusing solvents. We took the opportunity to study the activities of a number of serum enzymes in this population.

\section{Subjects and methods}

Between November 1979 and March 1983296 young persons ( 263 male and 33 female) aged between 7 years 11 months and 19 years 4 months were referred by the authorities, usually the police, or parents to a psychiatric outpatient clinic at the London Road Police Office, Glasgow, for counselling following solvent abuse. The subjects, accompanied 
by their parents or guardians, were interviewed and counselled by a community police officer and then by a psychiatrist, who, with informed consent, took a blood sample for the purpose of detecting subclinical disease. All subjects were of average health.

Thirty six subjects were seen on more than one occasion, usually within eight weeks of first attending. Three subjects were seen again after a year and one after three years. During the study two subjects who were severely intoxicated and suffering from self neglect and lack of supervision were admitted to a psychiatric hospital and a few others received outpatient treatment related to family problems.

Samples were analysed for aspartate transaminase (AST; EC 2.6.1.1) ${ }^{8}$ alanine transaminase (ALT; EC 2.6.1.2), ${ }^{8}$ alkaline phosphatase (ALP; EC 3.1.3.1) ${ }^{9} \quad \gamma$-glutamyltransferase $\quad$ (GGT; $\quad$ EC 2.3.2.2), ${ }^{10}$ and creatine kinase (EC 2.7.3.2). ${ }^{11}$ All analyses were performed at $37^{\circ} \mathrm{C}$ using a Centrifichem 400 (Baker Instruments, USA).

CK B subunit activity was determined on a LKB 2086 Reaction Rate Analyser (LKB, Sweden) with blank subtraction as recommended by the Scandinavian Committee on Enzymes. ${ }^{12}$ Reagents were supplied in kit form from E Merck (Darmstadt, FRG).

As the clinic is held in the evening, samples were stored as whole blood at ambient temperature and delivered to the laboratory the next morning. The effect such storage might have on enzyme activities was studied by taking 38 duplicate samples. One sample was centrifuged and the serum analysed promptly, while the other was stored unseparated for a further $18 \mathrm{~h}$. Statistical analyses of the paired results showed AST and ALT to be reduced by $2 \mathrm{U} / 1$ and $3 U / 1$ respectively $(p<0.01)$ at mean activities of $50 \mathrm{U} / 1$ and $30 \mathrm{U} / 1$ respectively after overnight storage of whole blood.

A separate experiment showed there was no loss of CK B subunit activity in 10 samples treated similarly.

\section{Results}

AST, ALT, ALP, AND GGT

Table 1 summarises the results for these enzymes.

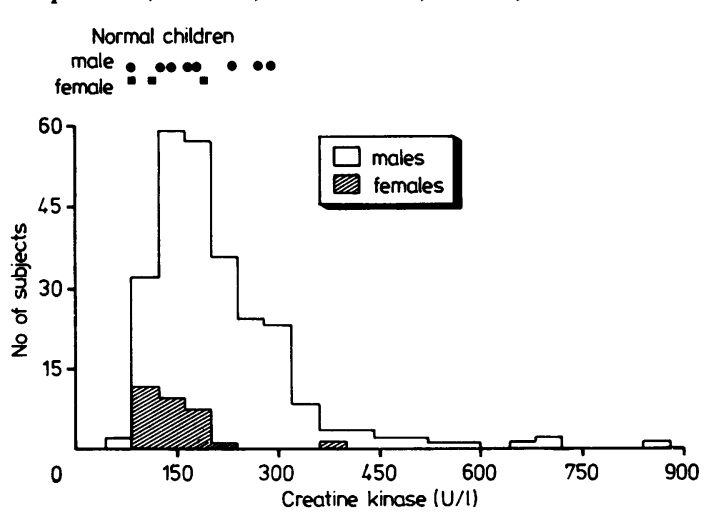

Fig. 1 Distribution of total creatine kinase (CK) activity in the serum of 263 males and 33 females abusing solvents. CK activity of samples from normal male and female subjects are also shown.

The distributions were tested for skewness using the equations given by Snedecor..$^{13}$ One subject had an increased AST activity and two had increased ALT activities as judged by adult reference ranges. This compares with the finding of no abnormalities of aminotransferase activity in a series of 115 subjects. ${ }^{14}$ The highest ALP activity was $1775 \mathrm{U} / 1$ with seven other values $>1000 \mathrm{U} / \mathrm{l}$, results in agreement with published data. ${ }^{15}$ No abnormal GGT values were found. The association of GGT activity with age in male subjects has been reported previously, ${ }^{16}$ and concurrent alcohol abuse seems the most likely explanation in our subjects.

\section{CK}

The distribution of total CK activities found in both sexes is shown in Fig. 1. This figure also includes results for children aged between 8 years and 15 years obtained from blood samples submitted for determination of cholinesterase genotype; we were unable to obtain a suitable control population from subjects not attending hospital.

Statistical analysis of the data is shown in Table 2. Four CK activities $>600 \mathrm{U} / \mathrm{l}$ were found, the highest being $870 \mathrm{U} / \mathrm{l}$, and all are included in the statis-

Table 1 Serum enzyme activities in 263 males and 33 females abusing solvents

\begin{tabular}{|c|c|c|c|c|c|c|c|c|}
\hline & \multicolumn{2}{|l|}{$A S T$} & \multicolumn{2}{|l|}{$A L T$} & \multicolumn{2}{|l|}{$A L P$} & \multicolumn{2}{|l|}{$G G T$} \\
\hline & Male & Female & Male & Female & Male & Female & Male & Female \\
\hline $\begin{array}{l}\text { Median activity (U/l) } \\
\text { Age relation (r) } \\
\text { Skewed distribution } \\
95 \% \text { confidence interval (U/l) }\end{array}$ & $\begin{array}{l}27 \\
-0 \cdot 185^{*} \\
\text { Yes } \\
9-45\end{array}$ & $\begin{array}{l}22 \\
\text { NS } \\
\text { No } \\
9-35\end{array}$ & $\begin{array}{l}18 \\
\text { NS } \\
\text { Yes } \\
4-30\end{array}$ & $\begin{array}{l}15 \\
\text { NS } \\
\text { No } \\
8-30\end{array}$ & $\begin{array}{l}493 \\
\text { NS } \\
\text { Yes } \\
145-1000\end{array}$ & $\begin{array}{l}318 \\
-0.523+ \\
\text { Yes } \\
130-820\end{array}$ & $\begin{array}{l}13 \\
0 \cdot 302 \dagger \\
\text { Yes } \\
9-25\end{array}$ & $\begin{array}{l}10 \\
\text { NS } \\
\text { No } \\
4-20\end{array}$ \\
\hline
\end{tabular}

NS $=$ no significant correlation.

${ }^{*} \mathrm{p}<0.05$; $\mathrm{tp}<0.001$. 
Table 2 Creatine kinase activities in 263 males and 33 females abusing solvents

\begin{tabular}{lcc}
\hline & Male & Female \\
\hline Median acitivity (U/l) & 185 & 142 \\
Age relation (r) & $0 \cdot 111^{*}$ & $-0 \cdot 275^{*}$ \\
Skewed distribution & Yes & Yes \\
95\% confidence interval (U/l) & $45-420$ & $\mathbf{8 0 - 2 4 0}$ \\
\hline
\end{tabular}

*No significant correlation.

tics. The negative association between $\mathrm{CK}$ and age seen in females, although not significant, is in keeping with the findings of Smith, ${ }^{7}$ who showed an oestrogen dependent reduction in CK at the menarche.

CK activity greater than $200 \mathrm{U} / \mathrm{l}$ was found in 119 subjects (40\%), comprising 117 males and two females. Whenever possible CK B subunit activity was measured on these samples, and a positive correlation ( $p<0.001$; Kendall Rank) between total $\mathrm{CK}$ and $\mathrm{B}$ subunit activity was found (fig. 2).

Fig. 2 contains a discriminant for abnormal CK B subunit activity. This discriminant combines the recommendations of the kit manufacturer (CK B subunit activity should be $<3 \%$ of total CK activity) and those of the Scandinavian Committee on Enzymes (CK B should be $<12 \mathrm{U} / \mathrm{l}$ at $\left.37^{\circ} \mathrm{C}\right)^{1217}$ and encompasses the $97 \%$ confidence limits for a normal population.

On the basis of this discriminant five subjects were identified as having raised circulating CK B subunit activities. Further samples were obtained from four of these and additional investigations are detailed in Table 3. In three subjects the presence of a raised CK B subunit activity was confirmed using an immunoinhibition technique with a kinetic bioluminescent end point (LKB, Sweden). The sample from the fourth subject was not available at this time. Using electrophoresis on cellulose acetate ${ }^{18}$ it was only possible to visualise CK MM in all four subjects.

Specific radioimmunoassays for CK $\mathrm{MB}$ and $\mathrm{CK}$ $\mathrm{BB}^{19}$ showed increased circulating $\mathrm{CK} \mathrm{BB}$ in two subjects. The thermal inactivation test proposed for

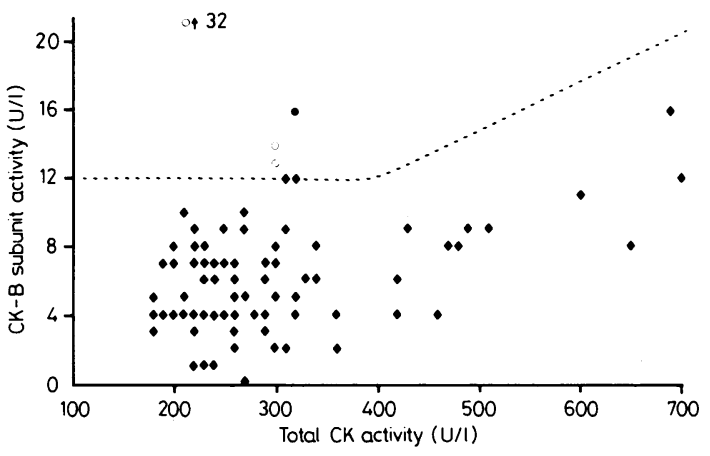

Fig. 2 Association between total creatine kinase (CK) and $C K B$ subunit activity in the serum of 90 young persons abusing solvents. Circles represent subjects thought to have increase $C K B$ activity; the closed circle represents the subject not available for follow up. Broken line represents the discriminant; $C K B=12 \mathrm{U} / \mathrm{l}$ or $3 \%$ of the total $C K$ activity.

the detection of macro $\mathrm{CK}$ complexes ${ }^{20}$ was unsatisfactory owing to the low initial activities.

\section{Discussion}

It is unusual for $\mathrm{CK}$ activities to be requested in children, the notable exception being in the investigation of muscular dystrophy. Here detection of carrier state requires well documented reference ranges. The published work, however, contains conflicting reports concerning the age and sex relations of CK.

It is accepted that CK activities are higher in neonates than in children and adolescents. ${ }^{1721}$ Ranges derived for children and young persons either show close adherence to the adult reference range $^{21}$ or show larger variations in activity, particularly in males, ${ }^{6}$ similar to the findings of the present study. Where ranges are derived from subjects attending hospitals ${ }^{21}$ it is likely that many of the demographic variables which might affect plasma constituents of a typical solvent abuser have been

Table 3 Further investigations of subjects with abnormal creatinine kinase B subunit activities

\begin{tabular}{|c|c|c|c|c|c|c|}
\hline $\begin{array}{l}\text { Patient } \\
\text { no }\end{array}$ & Date & $\underset{(U / l)}{\text { Total }} C K$ & $\underset{(U / l)}{C K} B$ & $\begin{array}{l}C K B \text { (as \% } \\
\text { of total) }\end{array}$ & $\begin{array}{l}C K M B^{*} \\
(n g / m l)\end{array}$ & $\begin{array}{l}C K \cdot B B \dagger \\
(n g / m l)\end{array}$ \\
\hline $\begin{array}{l}1 \\
2 \\
3 \\
4\end{array}$ & $\begin{array}{r}6.1 .81 \\
9.2 .81 \\
18.8 .81 \\
4.9 .81 \\
30.3 .82 \\
26.4 .82 \\
24.6 .80 \\
9.7 .80\end{array}$ & $\begin{array}{l}545 \\
291 \\
199 \\
177 \\
294 \\
179 \\
220 \\
143\end{array}$ & $\begin{array}{l}\text { Insuff } \\
13 \\
14 \\
15 \\
14 \\
8 \\
32 \\
21\end{array}$ & $\begin{array}{c}- \\
4 \cdot 5 \\
7 \\
8 \cdot 5 \\
4 \cdot 8 \\
4 \cdot 5 \\
14 \cdot 6 \\
14 \cdot 7\end{array}$ & $<2$ & 10 \\
\hline
\end{tabular}

CK $=$ creatinine kinase.

*Normal $<50 \mathrm{ng} / \mathrm{ml}$.

†Normal $<3 \mathrm{ng} / \mathrm{ml}$.

Insuff $=$ insufficient sample for analysis on this occasion. 
removed. In our study all subjects had been referred for counselling following recent abuse of solvents and, although judged to be in good health by the examining physician, they cannot be regarded as strictly normal. The results of the study do give guidelines as to the expected values in this age group. In the absence of a truly representative control group, we thought it worthwhile to confirm that the increases in total CK activity were due to increased CK MM isoenzyme.

The results show that only two subjects had demonstrable increases in an isoenzyme of CK other than MM and three others were thought to have abnormal B subunit activities. Most of the subjects with apparently raised $\mathrm{CK}$ activities had $\mathrm{B}$ subunit activities $<3 \%$, consistent with the observation that skeletal muscle contains a small percentage of CK $\mathrm{MB}$ isoenzyme ${ }^{22}$ and supporting the suggestion that release of CK from muscle by physical activity is responsible for the raised $\mathrm{CK}$ activities seen.

The most likely form of circulating B subunit in normal subjects is CK BB in the form of a macro CK, type $1 .{ }^{17}$ Macro CK, type 1 , a CK BB immunoglobulin complex, has not yet been associated with any disease. It is found in up to $6 \%$ of patients in hospital, ${ }^{17}$ often without an associated increase in total $\mathrm{CK}$ activity. In our population macro CK occurred in at least $2 \%$ and may have been as high as $11 \%$ if all five subjects considered to have an increased B subunit activity are included. Macro CK is commonest in elderly women ${ }^{17}$ but its incidence in young persons has not been previously assessed.

There is an inverse relation between CK BB and age; ${ }^{23} 24$ and with one report (using a specific radioimmunoassay) showing $\mathrm{CK} B \mathrm{~B}$ to be higher in 14 year old than in 8 year old and 25 year old subjects, the incidence of suspected macro CK in our population may be related to the natural distribution of CK BB.

Although the increases in CK found in young persons abusing solvents are primarily the CK MM isoenzyme, this does not eliminate the possibility that some component of the increase is due to solvent related muscle injury. The increases in CK following acute alcohol ingestion are due to CK MM. ${ }^{25}$

This report confirms the findings of Watson ${ }^{14}$ that biochemical monitoring of solvent abusers does not show serious biochemical abnormalities. With the increasing evidence of specific lesions, however, ${ }^{1-3}$ it is important that biochemical surveillance is maintained.

We thank Dr S Rosalki for help with the electrophoresis of samples Dr CP Price for arranging the specific radioimmunoassays, Dr WHS Thomson for useful discussion, and Mr Patrick Hamill QPM, Chief Constable, Strathclyde Police Force, for his cooperation in the running and staffing of the Solvent Abuse Clinic.

\section{References}

' King MD, Day RE, Oliver JS, Lush M, Watson JM. Solvent encephalopathy. Br Med J 1981;283:663-5.

${ }^{2}$ Allister C, Lush M, Oliver JS, Watson JM. Status epilepticus caused by solvent abuse. Br Med J 1981;283:1156.

${ }^{3}$ O'Brien ET, Yeoman WB, Hobby JAE. Hepatorenal damage from toluene in a "glue sniffer". Br Med J 1971;ii:29-30.

4 Wyse DG. Deliberate inhalation of volatile hydrocarbons: a review. Can Med Ass J 1973;108:71-4.

s King SW, Statland BE, Savory J. The effect of a short burst of exercise on activity values of enzymes in sera of healthy young men. Clin Chim Acta 1976;72:211-8.

- Cherian AG, Hill JG. Age dependence of serum enzymatic activities (alkaline phosphatase, aspartate aminotransferase and creatine kinase) in healthy children and adolescents. Am J Clin Pathol 1978;70:783-9.

'Smith I, Elton RA, Thomson WHS. Carrier detection in $\mathrm{X}$-linked recessive (Duchenne) muscular dystrophy: serum creatine phosphokinase values in premenarchal, menstruating, post menopausal and pregnant normal women. Clin Chim Acta 1979;98:207-16.

- Empfehlungen der Deutsche Gesellschaft fur Klinische Chemie: standardiserung von methoden zur bestimmung von enzymaktivitaten in biologishen flussigkeiten. Z Klin Chem Klin Biochem 1972;10:82-92.

9 Scandinavian Committee on Enzymes. Recommended methods for the determination of four enzymes in blood. Scand J Clin Lab Invest 1974;33:291-306.

${ }^{10}$ Persijn PJ, van der Slik W. A new method for the determination of $\gamma$-glutamyltransferase in serum. J Clin Chem Clin Biochem 1976;14:421-7.

"Scandinavian Committee on Enzymes. Recommended method for the determination of creatine kinase in blood, modified by the inclusion of EDTA. Scand J Clin Lab Invest 1979;39:1-5.

${ }^{12}$ Scandinavian Committee on Enzymes. Creatine kinase (EC 2.7.3.2) and creatine kinase B subunit activity in serum in suspect myocardial infarction. The Nordic Clinical Chemistry Project (Nordkem), Helsinki, Finland 1981.

${ }^{13}$ Snedecor GW. Statistical methods. Iowa: Iowa State University Press, 1956.

14 Watson JM. Clinical and laboratory investigations in 132 cases of solvent abuse. Med Sci Law 1978;18:40-3.

${ }^{15}$ Pentilla IM, Jokela HA, Vitala AJ, Hekkinene E, Nummi S, Pystynen P, Sasstomoinen J. Activities of aspartate and alanine aminotransferases and alkaline phosphatase in sera of healthy subjects. Scand J Clin Lab Invest 1975;35:275-84.

${ }^{16}$ Knight JA, Haymond RE. $\gamma$-Glutamyltransferase and alkaline phosphatase activities compared in serum of normal children and children with liver disease. Clin Chem 1981;27:48-51.

${ }^{17}$ Lang $\mathrm{H}$, Wurzburg U. Creatine kinase, an enzyme of many forms. Clin Chem 1982;28:1439-47.

${ }^{18}$ Rosalki SB. Creatine kinase isoenzyme demonstration and measurement. ACP Broadsheet 106, 1982.

19 Thompson RJ, Graham JG, McQueen INF, Kynoch PAM, Brown KW. Radioimmunoassay of brain type creatine kinase-BB isoenzyme in human tissues and in serum of patients with neurological disorders. $J$ Neurol Sci 1980;47:241-5.

${ }^{20}$ Bohner J, Stein W, Renn W, Steinhart R, Eggstein M. Stability of macro creatine kinases and creatine kinase isoenzymes compared: heat inactivation test for determination of thermostable creatine kinases.J Clin Chem Clin Biochem 1981;19:1021-6. 
${ }^{21}$ Kupke IR, Tritschler W, Kather B, Bablok W. Creatinkinase NAC-aktiviert: referenzwerte bei kindern. Klin Paediatr 1980; 192:348-50.

${ }^{22}$ Neumeier D. Tissue specific and subcellular distribution of creatine kinase isoenzymes. In: Lang $\mathrm{H}$ ed. Creatine kinase isoenzymes: pathophysiology and clinical application. Berlin: Springer-Verlag, 1981:85-109.

${ }^{23}$ Jung K, Neumann R, Cobet G, Nugel E, Egger E. Creatine kinase isoenzyme BB in serum of healthy adults and children. Clin Chim Acta 1979;91:165-8.
${ }^{24}$ Urdal P, Urdal K, Stromme JH. Age related reference intervals for creatine kinase BB in serum. Scand J Clin Lab Invest 1982;42:621-5.

${ }^{25}$ Kettunen P. Activity of creatine kinase isoenzymes in the serum after acute alcohol intake and in chronic alcoholism. Scand J Clin Lab Invest 1982;42:303-5.

Requests for reprints to: Dr RJ Spooner, Biochemistry Department, Gartnavel General Hospital, 1053 Great Western Road, Glasgow G12 0YN, Scotland.

\section{The March 1984 issue}

\section{THE MARCH 1984 ISSUE CONTAINS THE FOLLOWING PAPERS}

Lymphoproliferations in the bone marrow: identification and evolution, classification and staging R BARTL, B FRISCH, R BURKHARDT, K JÄGER, R PAPPENBERGER, G HOFFMANN-FEZER

Detection and identification of serum monoclonal immunoglobulin by immunoisoelectric focusing. Limits of sensitivity and use during relapse of multiple myeloma D SINCLAIR, DS KUMARARATNE, DI STOTT

Measurement of serum $C$ reactive protein concentration after bone marrow transplantation for leukaemia IF ROWE, AM WORSLEY, P DONNELLY, D CATOVSKY, JM GOLDMAN, DAG GALTON, MB PEPYS

A quantitative study of eosinophil polymorphs in Hodgkin's disease WJ FUGGLE, J CROCKER, PJ SMITH

Tuberous sclerosis: unusual associations in four cases EB ILGREN, D WESTMORELAND

Hepatic metastases in a case of intravascular bronchioloalveolar tumour ANN GLEDHILL, JM KAY

Small intestinal mucosal abnormalities in postperinatal deaths S VARIEND, R SUNDERLAND

Histochemical demonstration of acetylcholinesterase in neuroblastoma S VARIEND, MA LOUGHLIN

Increased $\alpha$-fetoprotein concentration in association with ileal adenocarcinoma complicating Crohn's disease M LEADER, JR JASS

Intestinal lactase, sucrase, and alkaline phosphatase in 373 patients with coeliac disease JG O'GRADY, FM STEVENS, R KEANE, EM CRYAN, B EGAN-MITCHELL, B MCNICHOLL, CF MCCARTHY, PF FOTTRELL

Exocrine pancreatic function in diabetes mellitus $P$ DANDONA, DB FREEDMAN, Y FOO, J PERKINS, A KATRAK, DP MIKHAILIDIS, SB ROSALKI, AG BECKETT
Increased angiotensin-converting enzyme activities in diabetes mellitus: analysis of diabetes type, state of metabolic control and occurrence of diabetic vascular disease G SCHERNTHANER, CH SCHWARZER, R KUZMITS, MM MÜLLER, U KLEMEN, H FREYLER

Measurement of total bile acids in gastric juice BJ COLLINS, PCH WATT, THERESA O' REILLY, RJ MCFARLAND, AHG LOVE

Colorimetric enzymatic measurement of serum total $3 \alpha$-hydroxy bile acid concentrations without extraction MY QURESHI, SM SMITH, GM MURPHY

Comparison of results from two antibiotic susceptibility testing trials that formed part of the United Kingdom national external quality assessment scheme JJS SNELL, DFJ BROWN, PS GARDNER

A modified azoalbumin technique for the assay of proteolytic enzymes for use in blood group serology PK PHILLIPS, DILYS PRIOR, B DAWES

Comparison of the sensitivity of three methods for the rapid identification of Cryptococcus neoformans J COHEN

Neutropenic enterocolitis due to Clostridium septicum infection A KING, ANITA RAMPLING, DGD WIGHT, RE WARREN

Identification of the Enterobacteriaceae: a comparison of the Enterotube II with the API 20E LJ HAYEK, GW WILLIS

Is the antimicrobial removal device a cost-effective addition to conventional blood cultures? ROSEMARY MUNRO, PJ COLLIGNON, TANIA C SORRELL, P TOMLINSON

\section{Technical method}

Image analysis - a quantitative technique for studying normal and diseased microvasculature RAJ SPENCE, R MCCONNELL, JM SLOAN, IV ALLEN

\section{Letters to the Editor}

Book Reviews

Copies are still available and may be obtained from the PUBLISHING MANAGER, BRITISH MEDICAL ASSOCIATION, TAVISTOCK SQUARE, LONDON WC1H $9 \mathrm{JR}$, price $£ 5 \cdot 00$, including postage 